\title{
Perceptions of Climate Change among Grade 11 Learners in the Tshwane Metropolitan Municipality, South Africa
}

\author{
Mapaleng Silas Lekgeu and Nerhene Davis, Department of Geography, \\ Geo-informatics and Meteorology, University of Pretoria, South Africa
}

\begin{abstract}
Of all the environmental problems facing humankind today, anthropogenic-induced climate change is regarded as one of the most damaging in its potential repercussions. For this reason, the perceptions of climate change among high-school learners, who represent future decision-makers and stand as a proxy for the next generation, are of importance. This study was designed so as to gain insight into the nature of perceptions and associated determinants among Grade 11 learners in the Tshwane metropolitan municipal area. Specifically, it probed dynamics between the content in the formal curriculum (Curriculum and Assessment Policy Statement or CAPS) and learners' exposure to electronic media, their peers and parents (their arenas of social interaction) in forming these perceptions. The study involved a qualitative analysis of 68 questionnaires completed by learners from two high schools. Findings include misconceptions regarding climate change among learners, as they conflate climate change and the greenhouse effect. The learners' perceptions seem to be shaped by the cumulative outcomes of dynamics between different arenas of exposure and influence (formal education, peers, parents and the media). It is argued that learners' perceptions about climate change fostered in formal education should also be understood in the context of their potential exposure to: (1) alarmist framings of climate change in the media; (2) conceptual disagreements in the climate change research community; and (3) the influence of peers and parents. Rather than avoiding the dynamics from contesting and diverging 'arenas of exposure', future climate change education planning should accommodate and align contending views that might influence the learning process.
\end{abstract}

Keywords: Climate change, school curriculum, learner perceptions, media, peers.

\section{Introduction}

Climate change is a worldwide issue that is discussed in print and electronic media, as well as on social media. In both the developed and developing world, there is an abundance of often contradictory information about this environmental problem from many different sources, most of which is inconsistent with scientific studies (Ho, 2009). At the same time, the local impacts of climate change, and the causal and consequential factors as well as coping strategies, are still not easy to fathom and comprehend. The way in which the science of 
climatology describes and explains this complex phenomenon, and the scientific viewpoints that differ when attempting to identify the causes and consequences of climate change, exacerbates chances of misunderstandings developing among the public and learners.

Boyes and Stanisstreet (2001), Boyes, Chuchran and Stanisstreet (1993), and Liarakou, Athanasiadis and Gavrilakis (2011), who conducted studies in the United Kingdom (UK) and Greece, argue that misunderstandings about climate change are a worldwide phenomenon. There have also been concerns in recent years that sections of the public appear to have lost faith in climate science and scientists, and that the public and experts may increasingly be diverging in their assessments about climate change. Vujovic (2013) observed a growth in public scepticism about climate change (however defined) since the late 2000s. This has been attributed to a range of factors, including climate fatigue, misleading media representations, the global financial crisis of 2008, and social attenuation of risk (Capstick, Whitmarsh, Poortinga, Pidgeon \& Upham, 2015).

Vujovic (2013), for example, contends that the media have used sensationalism to draw the public's attention to climate change, resulting in many lay individuals forming extreme and alarmist perceptions of such change. In addition, the media's alarmist framing of climate change has resulted in individuals feeling overwhelmed by the magnitude of the issue (Swim et al., 2009). As a consequence, some have become apathetic concerning climate change, believing that they cannot meaningfully contribute to mitigating the issue owing to its perceived severity and enormity (Swim et al., 2009).

Teaching learners about climate change at all levels of formal education is a response designed to reduce misconceptions and levels of apathy in society (Anyanwu, Le Grange \& Beets, 2015). Ojala (2015) contends that climate change education at primary- and secondary-school level has the potential to develop awareness and improve understanding of this important issue. Wibeck (2014:391) asserts that this approach tends to frame climate change education in terms of the 'information deficit model', which treats formal education as the remedy for public distrust and lack of interest in climate change.

To date, research conducted in South Africa on learners' knowledge and perceptions of climate change has concentrated on a range of issues regarding the dynamics between learners and the content of the learning material (Vujovic, 2013) and between learners' knowledge and the teacher's capacity and understanding (Anyanwu et al., 2015). In this paper, it is argued that the nature of the perceptions or understanding of learners about climate change fostered in the formal education environment should also be understood in the context of their potential exposure to: (1) alarmist framings about climate change in the media; (2) conceptual disagreements in the climate change research community; and (3) the influences of their peers and parents. The main aim of this study is thus to establish how Grade 11 learners perceive and understand climate change, and then to try to unravel how these perceptions were formed, given learners' exposure to these different arenas of influence. The paper argues that learners' perceptions about climate change need to be understood as a cumulative outcome of contesting dynamics from diverging 'arenas of exposure'. This argument is aligned with the constructivist theory of learning as framed by Vygotsky, who emphasised that learning happens not only in the classroom context, but also through social interaction. 


\section{Literature Review}

While the introduction of the phenomenon of climate change in the formal education context is seen as an important remedy in eliminating misconceptions about, and apathy regarding, such change, research is, however, painting a fairly gloomy picture about the outcomes of the educational approach to climate change in formal education. Studies conducted in both developed and developing countries consistently find that young people still have misplaced views about climate change in the main. For example, learners think that air pollution and ozone depletion cause climate change, that reducing nuclear power diminishes global warming, or that the greenhouse effect causes skin cancer (Boyes \& Stanisstreet, 2001; Boyes et al., 1993; Liarakou et al., 2011; Sherpadson, Niyogi, Choi \& Charusombat, 2009). Learners also believe that global warming could be reduced by using unleaded petrol (Boyes \& Stanisstreet, 2001).

The UNICEF 2011 report entitled, Change through the eyes of a child: South African children speak about climate change, presented findings from focus-group discussions with children aged 14 to 17 in KwaZulu-Natal and Limpopo. The report concluded that the children were generally aware of the future impacts of climate change - many of them indicated that they would probably have to deal with serious diseases as a result of climate change when they become doctors. The children anticipated some economic impacts that climate change might have and were also able to mention strategies that could be deployed to mitigate the impacts of climate change. However, the report also concluded that the children's actual understanding and perception of climatic change was still somewhat distorted. A Gauteng-based study conducted by Vujovic (2013) makes a compelling argument that the nature of perceptions and misconceptions about climate change among South African learners could be the result of 'inconsistencies, misconceptions and gaps in the knowledge and perceptions of the teachers who instruct the learners'. Vujovic (2013) concludes from her analysis of 32 semi-structured interviews with high-school geography teachers that the majority of the teachers had a correct understanding of climate change-induced risks, but only a few had deeper scientific knowledge and understanding of these risks. Anyanwu et al. (2015) argue that the success of climate education requires teachers who are fully literate as regards climate change science so that they can explain the concepts underlying the causes and impacts of, and solutions to, climate change as accurately as possible. Their study of the literacy of geography teachers in the Western Cape showed that the teachers they interviewed displayed a moderately higher level of climate change literacy, but that misconceptions in all three categories of climate change science, as represented in their survey instrument, were evident (Anyanwu et al., 2015).

The physio-cultural milieu of learners also seems to affect their conception of climate change. Leftridge and James (1980), Bogner and Wiseman (1997), Ho (2009), and Pruneau, Gravel, Bourque and Langis (2003) all suggest that learners' physical closeness to a cultural environment (as in rural or urban settings) has a great impact on their environmental perceptions and attitudes, and on pro-environment behaviour in general. According to Bogner and Wiseman (1997), learners in rural milieus usually differ from those in urban milieus not only in their perception of the environment, but also in their behaviour and attitudes towards the environment. For example, 'while urban learners are more conservative and preservative 
about environmental issues, rural learners are more exploitative towards the environment due to the nature of their livelihoods and demand for human utility of natural resources' (Bogner \& Wiseman, 1997). Thus, if learners in different environments have different environmental views, they will perceive, understand and act differently concerning climate change, because one's immediate surroundings in which one might have lived since childhood usually influence one's perception of that place and of environmental issues in general (Ho, 2009; Lutz, SimpsonHousley \& De Man, 1999).

It could thus be anticipated that Grade 11 learners would perceive and understand climate change differently within the context of their age cohort as a result of different locational contexts. Other influences could be access to electronic media, especially television and the Internet. Indeed, Boyes and Stanisstreet (2001) and Liarakou et al. (2011), who studied learners' ideas about climate change in the UK and Greece, respectively, argue that young people with an open culture characterised by the accessibility of electronic-media facilities and by good education, and who reside in urban areas, are better informed about climate change than those who reside in rural areas characterised (in these instances) by less access to electronic-media facilities and by inferior education. Young people within the same age cohort who had less access to media and who had experienced inferior education showed - although at a low occurrence level - comprehension of some scientific concepts related to climate change, such as the fact that carbon dioxide is a greenhouse gas. In contrast, those who had greater access to electronic-media facilities showed an understanding of complex issues, including concern for sustainability and the different alternative methods of conserving the environment (e.g. through energy-efficiency practices, recycling paper, and decreasing industrial and vehicular emissions) (Boyes \& Stanisstreet, 2001). The reason advanced for this rural-urban dichotomy is that an open culture characterised by accessibility to media facilities encourages the acquisition of more knowledge, skills and values in matters relating to the environment (Boyes \& Stanisstreet, 2001; Daniel, Stanisstreet \& Boyes, 2004).

It is on the basis of these broader observations that a study was designed to establish whether or not Grade 11 learners in the City of Tshwane in South Africa perceive climate change differently as a result of exposure to differently configured arenas of influences (physio-cultural milieu, media, peers and parents).

\section{Case Study: Two Schools in the Tshwane Metropolitan Area}

The students sampled in this research project were all in Grade 11 in 2015 in the public-school system in Gauteng, South Africa. The study was conducted in the Tshwane Metropolitan Municipality (see Figure 1) and involved two high schools: Willowridge High School, which is situated in an urban area; and Wozanibone Secondary School, which is located in a peri-urban/ rural area. Dividing education provision into rural or urban is problematic, since the criteria normally used (e.g. population density, provision of services, land use, employment, etc.) are ever-changing (Statistics South Africa, 2003). But, for the purposes of this paper, the rural-urban distinction is based on the distinction as applied by the Gauteng Department of Basic Education in which land use and nature of employment are defining characteristics. In the present case, 
therefore, 'rural/peri-urban' refers to areas where land use is extensive and buildings are dispersed, whereas 'urban' refers to areas in which land use is intensive, with nucleated built-up areas.

The school curriculum in South Africa is standardised for the country as a whole, irrespective of whether residences are in urban or rural areas (excluding private schooling, which is not included here). Further, education in the country is unified around one curriculum policy called the Curriculum and Assessment Policy Statement (CAPS). According to the CAPS, by the end of Grade 5, learners are expected to know and explain: the difference between weather and climate; the different climates in South Africa; the climate of their own area; as well as factors that influence both of these systems, namely temperature, wind, air pressure and precipitation (South Africa, 2012). This is taught in Geography or Social Sciences, but also in Natural Sciences and Life Sciences subjects.

The study of weather and climate in the CAPS runs from Grade 5 through to Grade 11 at different levels, with the exception of Grade 7. In Grade 10, in particular, learners learn about: the impact of the greenhouse effect on people and the environment; global warming - evidence, causes and consequences, with reference to Africa; and the impact of climate change on Africa's environment and people, with reference to deserts, droughts, floods and rising sea levels. In Grade 11, learners learn about: Africa's weather and climate; Africa's climatic regions; subsidence and convergence, and the links to rainfall; the role of oceans in climate control in Africa; the El Niño and La Niña processes and their effects on Africa's climate; and reading and interpreting synoptic weather maps (South Africa, 2012).

Figure 1. Map of the areas where the two schools are located

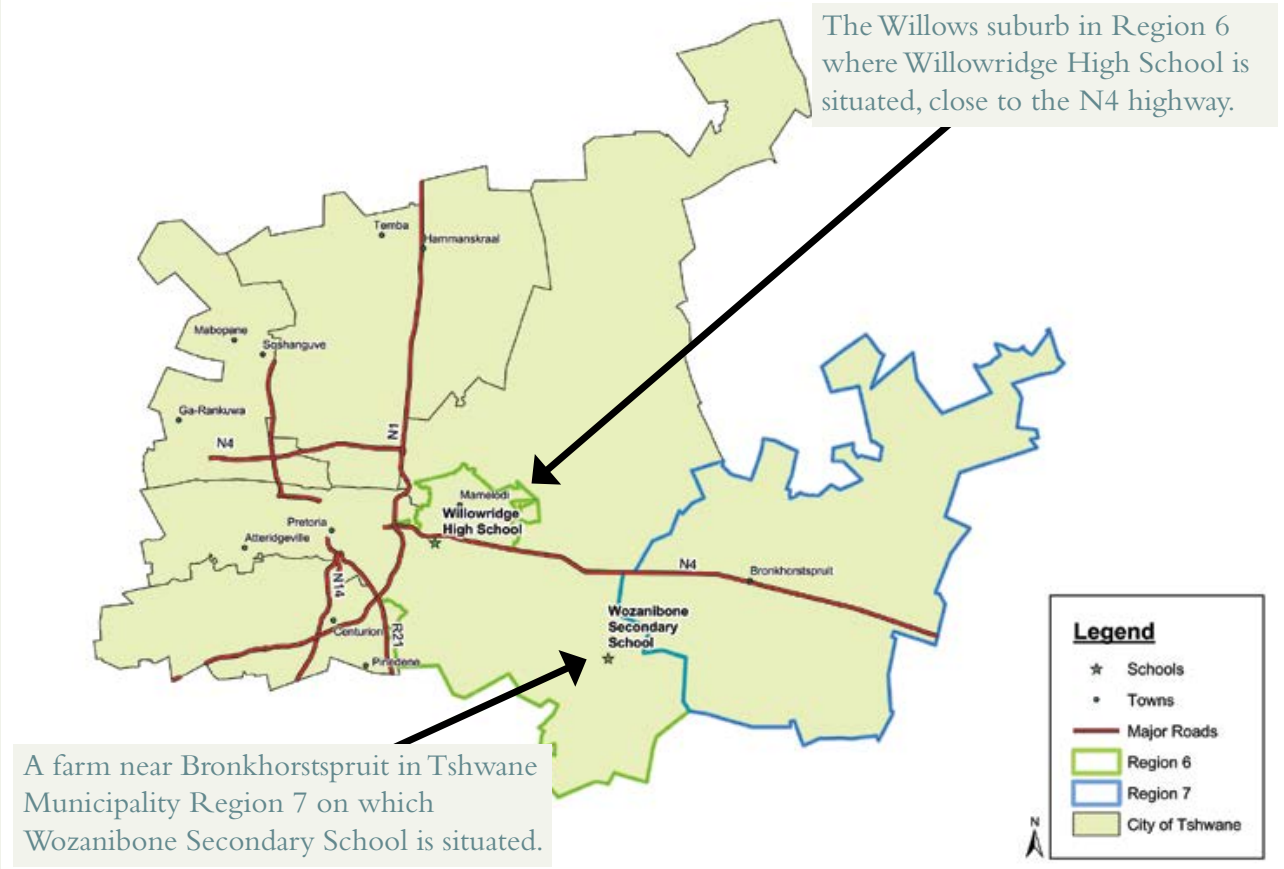

Source: Department of Geography, Unit for Geoinformatics and Meteorology, University of Pretoria 
From a total population of 2400 learners in 2015, the researchers purposefully sampled 30 learners doing Geography in Grade 11 at Willowridge, and 50 learners doing Geography at Wozanibone. Among the subjects, Geography offers the greatest opportunity for understanding climate change concepts because of its emphasis on place, spatial processes, spatial distribution, society and the environment. Geography is taught as a subdiscipline of Social Sciences in Grades 4 to 9 of the General Education and Training band, and as a specific subject in the Further Education and Training band (Grades 10 to 12) (DBE/RSA, 2011). Of the 30 learners sampled at Willowridge, 25 participated, whereas 43 of the 50 learners sampled at Wozanibone participated.

\section{Conceptual Framework}

If we are to understand how learning takes place, especially with regard to complex environmental issues such as climate change, an appreciation of how learner perceptions are formed and of the associated epistemology or understanding of knowledge, is needed. The learning theory of social constructivism posits that learning is the construction of knowledge, and that learning can only take place within a context of social interaction characterised by culturally based beliefs that, for example, both the teacher and the learners bring to the classroom. Learners' perceptions about environmental issues stem, therefore, not from scientific, logical processes, but from social interaction with others. For Wibeck (2014), the social-constructivist perspective is the ideal learning theory to assist educators to help learners not only to perceive but also understand climate change. Social constructivism promotes the significance of culture and context in comprehending how society operates, thereby constructing knowledge (Palincsar, 1998). In other words, it is when one understands his or her culture and the immediate surroundings that one will be able to construct meanings in respect of the situations and, in the process, learn about reality (Kim, 2001; Wibeck, 2014).

Palincsar (1998) considers Lev Vygotsky to be the key proponent of social constructivism and its perspective on the role of socio-cultural processes as a mechanism for learning. According to Vygotsky, as elucidated by Palincsar (1998), social interaction plays a fundamental role in the process of cognitive development, a process in which development is believed not to precede learning but rather that learning (and, specifically, social learning) precedes development. In other words, a child's cultural, cognitive development appears twice: first on the social level and, later, on the individual level, that is, first between people and then later inside the child. Therefore, individual development, including higher mental functioning, has its origins in social sources (e.g. interaction with peers, parents and the media).

According to Kim (2001), social constructivism emphasises the importance of culture and context in understanding what occurs in society and in constructing knowledge based on this understanding. Social constructivism, therefore, 'generally regards learning as the appropriation of socially derived forms of knowledge that are not simply internalised over time but are also transformed in idiosyncratic ways in the appropriation process' (Palincsar, 1998:365). Whitmarsh (2011:59) contends that 'there has been a shift away from seeing scientific literacy as defined by knowledge of abstract scientific 'facts', towards investigating the contextual meanings of science applied in everyday life'. There is some debate about how much the context in which learning 
takes place matters and about the variety of ways in which we can make sense of the world, based on what we already understand (Wibeck, 2014). Nonetheless, we can conclude that there is a need for anyone looking to facilitate learning to consider the communicative context for climate change education, and also to explore learners' already existing perceptions of climate change (Wibeck, 2014). From the social-constructivist perspective, it is thus anticipated that Grade 11 learners, while in the formal education system, are also exposed to influences arising from (1) alarmist media framings of climate change; (2) conceptual disagreements in the climate change research community; and (3) their peers and parents - all of which serve in 'constructing' their understanding of, and ideas about, climate change.

\section{Methodology}

The study is exploratory and descriptive in nature. Findings are not purported to be confirmatory. Instead, the researchers hope to contribute to conversations about climate change education based on the findings from this small sample of learners. To this end, semi-structured questionnaires consisting of both closed-ended questions (to assess factual and conceptual understanding) and open-ended questions were administered to 68 learners at the two schools concerned.

The following assumptions informed the research design: (1) that the quality of teaching at the two study sites might differ; (2) that the number of learners in class could influence learning outcomes; and (3) that socio-economic differences between the two schools would influence not only the knowledge of the learners but also their inclination towards translating awareness into action and behaviour.

\section{Data collection and analysis}

Since any study of education inevitably entails ethical considerations, especially if children are involved, ethical issues such as the following were identified and considered during the planning and other stages of the present study: protecting privacy and confidentiality; harm and risk; honesty and trust; ownership of data; and the offering of reciprocity where possible (Hammersley \& Traianou, 2012; Shenton, 2004).A request for permission to conduct research in the two schools was submitted to the Gauteng Department of Education, which granted approval. Such request was also submitted to the principals and the school governing bodies of the two participating schools, and, after initial approval by them, the parents/guardians of the learners sampled were also asked for permission to interview learners. All respondents, including the teachers, signed a letter of informed consent agreeing to help with the study. Questionnaires were numbered, rather than named, to protect the identity of the learners. Learners, teachers and parents were reminded that participation was completely voluntary.

The questionnaires were handed out to the learners in the first term of the 2015 academic year. It should be noted that the Grade 11 learners would have done much of the climate change work in the previous year, as per the CAPS curriculum for Grade 10. Before the interviews were conducted, the researchers confirmed with the teachers that the learning units covering the climate change content had already been covered for the Grade 11 academic year. 
The first part of the questionnaire generated a profile consisting of answers to general demographic questions. Here, the learners were also asked about their 'social-interaction' networks. This included the type and the frequency of conversations learners would have with parents and peers about socially or environmentally relevant issues. The learners were also probed about their exposure to media sources, the nature of the content they would browse, the time they would spend reading environmentally related content, and the types of programmes they would watch on TV or download from the Internet. Learners were also asked whether they read newspapers and which parts of the newspapers they would read.

The second part of the questionnaire sought to gain insights regarding the knowledgeability of the learners. A range of questions was adapted from existing climate change literacy questionnaires (e.g. Anyanwu et al., 2015) in order to assess the learners' knowledge and understanding of basic concepts and terminology associated with climate change, specifically: (1) how climate change happens; (2) what the natural causes of climate change are; (3) the human activities that exacerbate the climate change process; and (4) what the enhanced greenhouse effect is. For the factual components, learners' responses were awarded a mark out of 20 ( 2 marks for each correct response).

The next part of the questionnaire dealt with conceptual items, that is, it assessed the learner's understanding of the processes and causes, impacts and solutions related to addressing climate change. For this part of the questionnaire, learners were also awarded a mark out of 20 (2 marks for a correct response). Procedural items assessed the learner's awareness of methods for solving problems relating to climate change. This part of the questionnaire was assessed by means of open-ended questions, and, here, a mark out of 20 was allocated to the thinking and application processes the learners were able to display.

The final section of the question paper asked learners about their personal perceptions concerning climate change - its causes, impacts and potential solution. These questions were carefully framed to try to gain perspective on learners' underlying thoughts/feelings (here called perceptions) about what they had been taught. This part was analysed by means of thematic coding and content analysis geared to flagging articulations that could represent perceptions/ feelings of 'apathy' or 'despondence' on the hand, compared with articulations reflecting 'optimism' and 'confidence' about humankind's prospects of achieving solutions for climate change-related problems, as well as their own role in achieving these outcomes, on the other. Learners who displayed a level of reasonable optimism and confidence were awarded the full ten marks. Those who expressed disinterest or apathy were awarded a mark of zero, with a mark of five being awarded in instances where the learners' perception of future prospects seemed a bit more 'mixed'. Each of the questionnaires thus received a final score out of 70 .

Once the marks were allocated for the questionnaires, subgroupings were identified. Learners who obtained fairly low scores ranging between 0 and 34 were labelled as the grouping with a 'low climate change literacy'; learners who scored between 35 and 50 were deemed to have 'moderate climate change literacy'; and learners who scored between 51 and 70 were regarded as respondents with 'high climate change literacy'. Once the subgroupings were identified, the demographic and other determinants were identified for key trends in describing these subgroupings. Before unpacking the results, the following section provides a short, descriptive overview of the profile of the respondents involved in this study. 


\section{Respondents' profile}

The Grade 11 learners generally ranged in age from 15 to 18 years. Table 1 indicates that the majority of the learners involved in the study were 17 years old. Moreover, the majority $(58 \%)$ of the respondents were male. Willowridge had more male respondents (66.7\%) than Wozanibone (45.5\%).

Willowridge also had a higher proportion of younger learners when compared with Wozanibone. It was noted during the interviews that nine learners $(27 \%)$ from Wozanibone were repeating their grade. This could account for the differences in the age groups between the two schools. The reasons for this could be that, in urban areas, which is where Willowridge is situated, most if not all learners finish school without interruptions, whereas in peri-urban areas, which is where Wozanibone is situated and which comprise predominantly farmland, many learners do not finish school. In fact, some start school when they have already past schoolgoing age. In these farming communities, learners' school programmes are interrupted more often due to the need to look for work in order to supplement or generate household income. Such learners then return to school some years later, if at all.

In terms of race, black learners formed the majority of the respondents from both schools. The respondent profile for Wozanibone was more homogenous, consisting of 3.1\% Coloured and $96.9 \%$ black learners. Willowridge had a more mixed profile of $18.8 \%$ white learners, $75 \%$ black learners, $4.2 \%$ Coloured learners, and 2\% Indian learners.

Table 1. Respondents' profile, with socio-economic status estimated based on devices and amenities

\begin{tabular}{|c|c|c|c|c|}
\hline \multirow[b]{2}{*}{ Variables } & \multicolumn{2}{|c|}{ Wozanibone Secondary School } & \multicolumn{2}{|c|}{ Willowridge Secondary School } \\
\hline & $\begin{array}{l}\text { Number of } \\
\text { learners }\end{array}$ & $\begin{array}{c}\text { Percentage } \\
(\%)\end{array}$ & $\begin{array}{l}\text { Number of } \\
\text { learners }\end{array}$ & $\begin{array}{c}\text { Percentage } \\
(\%)\end{array}$ \\
\hline \multicolumn{5}{|c|}{ Gender } \\
\hline Male & 15 & 45.5 & 32 & 66.7 \\
\hline Female & 18 & 54.5 & 16 & 33.3 \\
\hline \multicolumn{5}{|c|}{ Age group } \\
\hline $15-17$ & 11 & 33.3 & 38 & 79.2 \\
\hline $18-20$ & 15 & 45.5 & 8 & 16.7 \\
\hline $20+$ & 4 & 12.1 & 0 & 0 \\
\hline Unknown & 3 & 9.1 & 2 & 4.1 \\
\hline \multicolumn{5}{|c|}{ Race } \\
\hline Black & 32 & 96.9 & 36 & 75 \\
\hline Coloured & 1 & 3.1 & 2 & 4.2 \\
\hline White & 0 & 0 & 9 & 18.8 \\
\hline Indian & 0 & 0 & 1 & 2 \\
\hline \multicolumn{5}{|c|}{ Socio-economic status } \\
\hline Low-income & 22 & 66.7 & 7 & 14.6 \\
\hline Middle-income & 7 & 21.1 & 8 & 16.7 \\
\hline High-income & 2 & 6.1 & 28 & 58.3 \\
\hline Unknown & 2 & 6.1 & 5 & 10.4 \\
\hline
\end{tabular}


To gain a sound understanding of the profile of the respondents, their access to, and use of, electronic-media devices were also quantified, with the following 'ranking' system being used to distinguish between learners with 'good', 'moderate' and 'poor' access to electronic devices. The number of devices and electronic amenities the learner had access to at home was also given a score to stand as proxy for the 'socio-economic' status of the learner's household. Table 2 provides a summary of the calculations used to rank the learners' 'socio-economic income status' (indicated in Table 1) and their level of 'access to electronic media'.

Table 2. Ranking system for quantifying electronic-media use among the Grade 11 learners

\begin{tabular}{|c|c|c|c|c|}
\hline Mobile phone & Score & Actual score & \multicolumn{2}{|c|}{ Access to electronic media } \\
\hline Ordinary mobile & 1 & \multirow{3}{*}{$\begin{array}{l}\text { (Score allocated for } \\
\text { each device) }\end{array}$} & \multirow{3}{*}{$1-3$} & \multirow{3}{*}{ Poor } \\
\hline Mobile with some applications & 2 & & & \\
\hline Mobile with all applications & 3 & & & \\
\hline Television & Score & Actual score & \multirow{3}{*}{$4-6$} & \multirow{3}{*}{ Moderate } \\
\hline TV set at home & 1 & \multirow{5}{*}{$\begin{array}{l}\text { (Score allocated to } \\
\text { stand as proxy for } \\
\text { the socio-economic } \\
\text { income status of the } \\
\text { learner) }\end{array}$} & & \\
\hline TV with satellite dish & 2 & & & \\
\hline Computer at home & 3 & & \multirow{3}{*}{$5-6$} & \multirow{3}{*}{ Good } \\
\hline Computer with printer & 4 & & & \\
\hline Computer with Internet service & 5 & & & \\
\hline
\end{tabular}

The study also sought to identify learners' access to electronic media. The two charts in Figure 2 show the level of access to electronic media based on the calculations detailed in Table 2 . Figure 2 shows that the level of access to media in Wozanibone is quite poor when compared with that of Willowridge.

Figure 2. Level of access to electronic media in Wozanibone and Willowridge
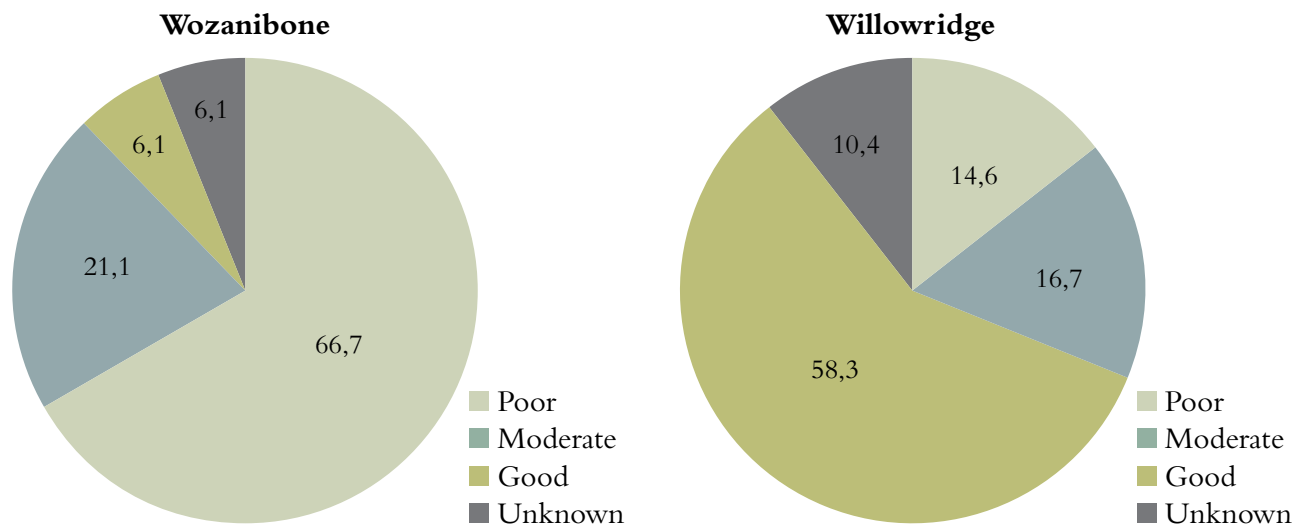

Learners were mostly exposed to electronic media such as mobile phones, television sets and computers. Respondents from Willowridge had a high level of access to electronic media but were not necessarily inclined to read articles related to climate change or the environment. 
A small percentage $(22 \%)$ of the total number of learners from both Willowridge and Wozanibone did, however, indicate that they (1) streamed climate- and environment-related media, and (2) talked to their peers and parents about environmental issues.

Table 3 provides a short summary of the key differences found between the two schools, thereby providing important background information for the analysis of the data.

Table 3. Determinants of climate change perception

\begin{tabular}{|c|c|c|}
\hline & $\begin{array}{l}\text { City of Tshwane Region } 7 \\
\text { (predominantly rural) }\end{array}$ & $\begin{array}{l}\text { City of Tshwane Region } 6 \\
\text { (Urban) }\end{array}$ \\
\hline & $\begin{array}{l}\text { Wozanibone Secondary } \\
\text { School }\end{array}$ & Willowridge High School \\
\hline \multirow[t]{2}{*}{ 1. Class size } & Grade 11 in 2015 & Grade 11 in 2015 \\
\hline & 50 learners in 1 class & 50 learners in 2 classes \\
\hline $\begin{array}{l}\text { 2. Socio-economic } \\
\text { conditions }\end{array}$ & $\begin{array}{l}\text { Low population density; } \\
\text { low education levels; high } \\
\text { unemployment ( } 26 \% \text { of } \\
\text { individuals were unemployed); } \\
\text { income from farming activities; } \\
\text { about } 22 \% \text { of dwelling units were } \\
\text { informal. (City of Tshwane, } 2014 \text { ) }\end{array}$ & $\begin{array}{l}\text { High population density; } \\
\text { high education levels; high } \\
\text { unemployment ( } 22 \% \text { of } \\
\text { individuals were unemployed); } \\
\text { income from tertiary and } \\
\text { quaternary activities; about } \\
22 \% \text { of dwelling units were } \\
\text { informal. (City of Tshwane, } 2014 \text { ) }\end{array}$ \\
\hline 3. Electronic media & $\begin{array}{l}\text { Not all respondents owned } \\
\text { smartphones. Of the sampled } \\
\text { respondents, } 33 \% \text { had their } \\
\text { TVs connected to a satellite } \\
\text { dish. Only } 23 \% \text { had access to } \\
\text { computers at home, but these } \\
\text { were not connected to any } \\
\text { Internet service. Poor access to } \\
\text { electronic media. }\end{array}$ & $\begin{array}{l}\text { While all respondents sampled } \\
\text { owned smartphones and } \\
\text { computers (with Internet service) } \\
\text { at home, not all had their TVs } \\
\text { connected to a satellite dish. } \\
\text { Respondents had adequate access } \\
\text { to electronic media. }\end{array}$ \\
\hline 4. Subject combination & $\begin{array}{l}\text { - } 2 \text { languages } \\
\text { - Geography/Business Studies/ } \\
\text { History } \\
\text { - Physical Sciences/Accounting/ } \\
\text { CAT } \\
\text { - Life Sciences/Economics/ } \\
\text { Tourism } \\
\text { - Mathematics/Mathematical } \\
\text { Literacy } \\
\text { - Life Orientation (LO) }\end{array}$ & $\begin{array}{l}\text { - } 2 \text { languages } \\
\text { - Geography/Accounting } \\
\text { - Physical Sciences/Business } \\
\text { Studies } \\
\text { - Life Sciences/Economics } \\
\text { - Mathematics/Mathematical } \\
\text { Literacy (or vice versa) } \\
\text { - Life Orientation (LO) }\end{array}$ \\
\hline
\end{tabular}

\section{Results}

This section provides a summary of the key findings resulting from the research. As far as possible, the data was disaggregated and correlated with the learners' age, race and gender. The association between race and the scores obtained by learners was inconclusive, especially since 
the majority of the sample consisted of black learners. However, the level of association between the gender of the learners and the scores obtained by them was quite revealing.

Figure 3 shows that females from both schools generally scored higher than their male counterparts in terms of the climate literacy criteria used in this study. Even more interestingly, when looking at the browsing activities of the learners (Figure 4), it is noted that female learners were more likely than male learners to read articles on climate change and the environment.

Figure 3. Average score of learners by gender (percentage)

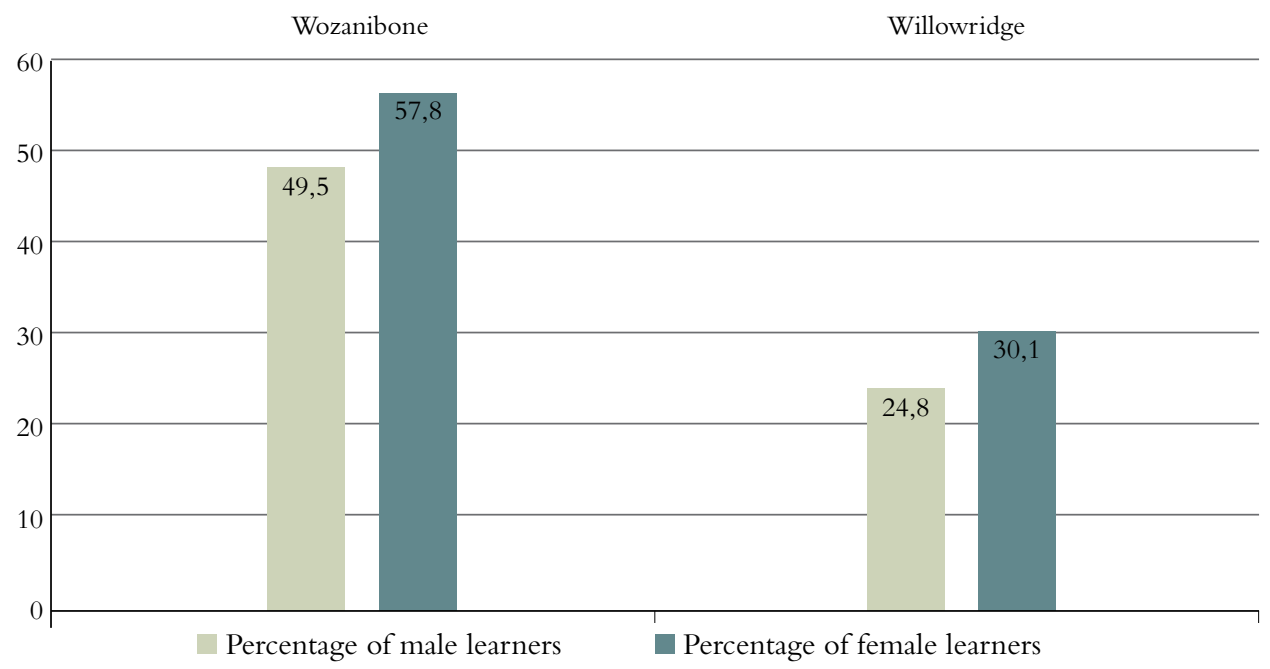

Figure 4. Browsing interests of learners

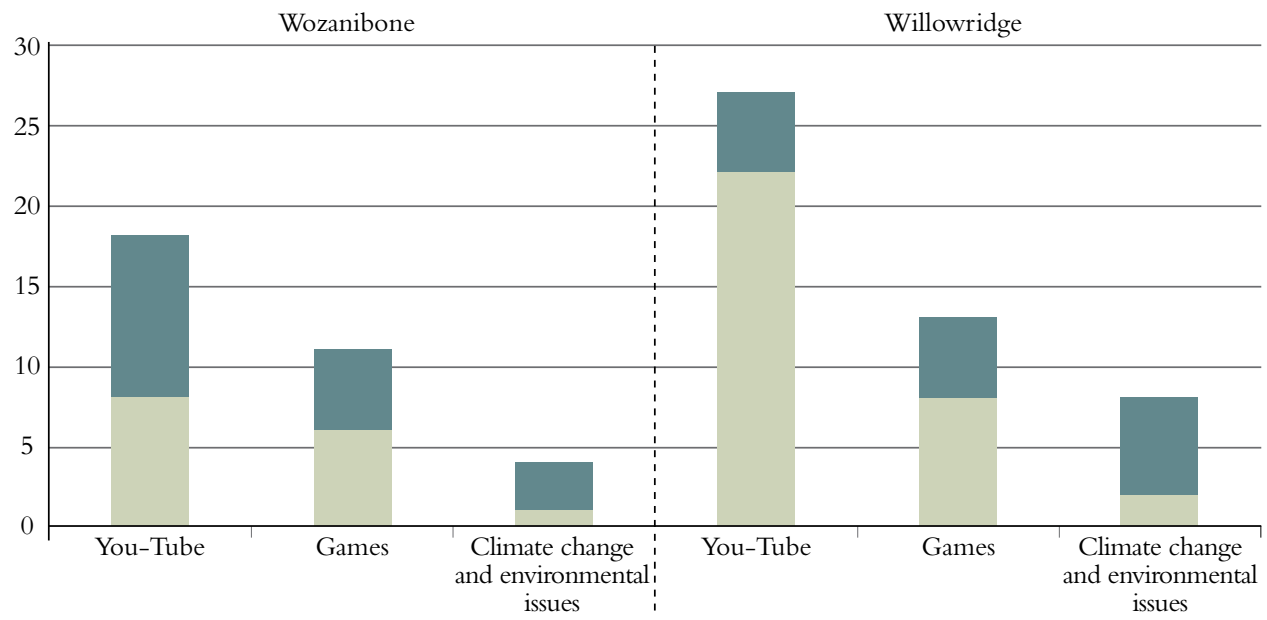

Number of male learners Number of female learners 
The strong association depicted in Figure 4 between the learners' exposure to electronic media and their scores (performance) hints at the potential importance of exposure to media as an avenue of influence in learners' perceptions and understanding of climate change. In this instance, the nature of the content being browsed is also of key importance: the results show that access to media is not automatically translating into higher levels of climate change literacy. Although learners from Willowridge all had access to cell phones, they reported not normally streaming clips or articles on climate change and the environment.

\section{Knowledge of greenhouse gases, the greenhouse effect and global warming}

The majority of the respondents who knew what the greenhouse effect and greenhouse gases are, and who also understood the connection between greenhouse gases and climate change, were from the peri-urban school, Wozanibone (83\%). Only 33\% of the learners from the urban school, Willowridge, performed well in this part of the questionnaire, which largely required rote responses with regard to acquired content knowledge. While the learners seemed aware of the relationship between greenhouse gases and global warming (see Table 4), they tended to confuse the greenhouse effect with climate change. Some suggested that cigarette smoke also contributes to the greenhouse effect and to climate change.

\section{Conceptualisation and application of climate change knowledge}

Learners were also asked to explain the linkages between natural and human activities in both causing and mitigating climatic variation, how causing such variation could entrench climate change impacts even further, and how a warming climate might influence farming, the oceans, the biomes and people's health (conceptualisation questions). This required a bit more application of knowledge and, in this instance, the urban learners tended to outperform their peri-urban counterparts in that they were better able to reflect the linkages between various processes and the impacts of climate change. In this case, $83 \%$ of the learners at the urban school, compared with $50 \%$ of the learners at the peri-urban school, depicted these linkages fairly accurately.

With regard to the ability to depict their understanding of climate change graphically, only $40 \%$ of the learners from the urban school and 39\% of the learners in the peri-urban school were able to draw fairly accurate graphic representations of climate change. It was also noted that the representations by $60 \%$ of the total number of learners seemed to conflate climate change and global warming, with many of the learners actually drawing the process of global warming.

By means of two open-ended questions, the procedural items assessed the learners' own understanding of suitable responses to climate change. A mark out of 20 was allocated to the thinking and application processes that the learners displayed. Only $28 \%$ of the urban-based learners and $16 \%$ of the learners in the rural/peri-urban context performed well in this part of the questionnaire.

Interestingly, during the initial analysis of the data, it seemed as if $100 \%$ of the rural/periurban learners had a firm grasp of suitable methods for solving problems related to climate change. But, in a second round of analysis, the responses were weighed more critically and 
Table 4. Summary of results

\begin{tabular}{|c|c|c|c|}
\hline & & $\begin{array}{l}\text { Wozanibone } \\
\text { (peri-urban) }\end{array}$ & $\begin{array}{l}\text { Willowridge } \\
\text { (urban) }\end{array}$ \\
\hline \multirow[t]{3}{*}{$\begin{array}{l}\text { Reproduction of } \\
\text { factual content }\end{array}$} & $\begin{array}{l}\text { Knowledge of the } \\
\text { greenhouse effect and of } \\
\text { global warming }\end{array}$ & $\begin{array}{l}\text { Of the sampled } \\
\text { respondents, } 83 \% \\
\text { showed a good } \\
\text { understanding of the } \\
\text { greenhouse effect and of } \\
\text { global warming. }\end{array}$ & $\begin{array}{l}\text { Of the sampled } \\
\text { respondents, 33\% } \\
\text { showed a good } \\
\text { understanding of the } \\
\text { greenhouse effect and of } \\
\text { global warming. }\end{array}$ \\
\hline & $\begin{array}{l}\text { Knowledge of the } \\
\text { sources of greenhouse } \\
\text { gases and of their } \\
\text { contributions to global } \\
\text { warming }\end{array}$ & $\begin{array}{l}\text { Of the sampled } \\
\text { respondents, } 100 \% \\
\text { showed a good } \\
\text { understanding of the } \\
\text { sources of greenhouse } \\
\text { gases and of their } \\
\text { contributions to global } \\
\text { warming. }\end{array}$ & $\begin{array}{l}\text { Of the sampled } \\
\text { respondents, } 33 \% \\
\text { showed a good } \\
\text { understanding of the } \\
\text { sources of greenhouse } \\
\text { gases and of their } \\
\text { contributions to global } \\
\text { warming. }\end{array}$ \\
\hline & $\begin{array}{l}\text { Knowledge of the effects } \\
\text { of excessive } \mathrm{CO}^{2} \text { and } \\
\text { of climate change in } \\
\text { general }\end{array}$ & $\begin{array}{l}\text { Of the sampled } \\
\text { respondents, } 50 \% \\
\text { showed a good } \\
\text { understanding of climate } \\
\text { change. }\end{array}$ & $\begin{array}{l}\text { Of the sampled } \\
\text { respondents, } 16 \% \\
\text { showed a good } \\
\text { understanding of climate } \\
\text { change. }\end{array}$ \\
\hline Conceptualisation & $\begin{array}{l}\text { Knowledge of the } \\
\text { causes and effects of } \\
\text { climate change (i.e. } \\
\text { understanding of the } \\
\text { linkages) }\end{array}$ & $\begin{array}{l}\text { Of the sampled } \\
\text { respondents, } 50 \% \\
\text { showed a good } \\
\text { understanding of the } \\
\text { causes and effects of } \\
\text { climate change. }\end{array}$ & $\begin{array}{l}\text { Of the sampled } \\
\text { respondents, } 83 \% \\
\text { showed a good } \\
\text { understanding of the } \\
\text { causes and effects of } \\
\text { climate change. }\end{array}$ \\
\hline $\begin{array}{l}\text { Application ability } \\
\text { of respondents }\end{array}$ & $\begin{array}{l}\text { Ability to depict climate } \\
\text { change graphically }\end{array}$ & $\begin{array}{l}\text { Only } 39 \% \text { of the } \\
\text { sampled respondents } \\
\text { were able to illustrate } \\
\text { their understanding of } \\
\text { climate change. }\end{array}$ & $\begin{array}{l}\text { Of the sampled } \\
\text { respondents, } 44 \% \text { were } \\
\text { able to illustrate their } \\
\text { understanding of climate } \\
\text { change. }\end{array}$ \\
\hline Procedural ability & $\begin{array}{l}\text { Knowledge of possible } \\
\text { solutions }\end{array}$ & $\begin{array}{l}\text { Of the sampled } \\
\text { respondents, } 16 \% \\
\text { showed a good } \\
\text { understanding of } \\
\text { possible strategies to } \\
\text { curb climate change. }\end{array}$ & $\begin{array}{l}\text { Of the sampled } \\
\text { respondents, } 28 \% \\
\text { showed a good } \\
\text { understanding of } \\
\text { possible strategies to } \\
\text { curb climate change. }\end{array}$ \\
\hline
\end{tabular}

judged to be variations of the same wording used to articulate recommended responses to climate change. This suggested to us that the learners in the peri-urban context were merely reproducing recommendations as presented by the teacher when she introduced the concepts to them. This was confirmed when we verified that the recommendations provided by the rural/peri-urban learners were also listed in the CAPS material. By contrast, the responses 
of the urban-based learners revealed attempts at demonstrating their own interpretation of the CAPS content by trying to draw on their own lived experiences. We decided to discount the responses which merely reproduced the conceptualisations framed by the teacher and the CAPS material, as this part of the questionnaire was aimed at gaining insights into the ability of the learners to translate new knowledge into practical application.

The surprisingly poor performance of the urban learners was also explained by the high number of non-responses $(n=10)$ in this part of the questionnaire. It would seem that, when the urban learners encountered the question, 'What recommendations would you make to combat climate change-related challenges?', they rightly assumed that they were expected to come up with their own recommendations, but were then unable to provide an answer. This was confirmed by one of the respondents asking why they were not allowed to google the answer to this question.

\section{Learners' perceptions of climate change}

As already mentioned, once a score was allocated for each of the questionnaires, subgroupings were identified. These are presented in Table 5.

Table 5. Climate change literacy and perception

\begin{tabular}{|l|c|c|}
\hline & Wozanibone & Willowridge \\
\hline 'High climate change literacy' & $7(16.2 \%)$ & $7(28 \%)$ \\
\hline 'Moderate climate change literacy' & $26(60.4 \%)$ & $15(60 \%)$ \\
\hline 'Low climate change literacy' & $10(23.2 \%)$ & $3(12 \%)$ \\
\hline Total & $\mathbf{N}=\mathbf{4 3}$ & $\mathbf{N}=\mathbf{2 5}$ \\
\hline
\end{tabular}

Willowridge performed slightly better in terms of the number of learners in the 'high climate change literacy' segment, with $28 \%$ of its respondents falling into this subgroup, compared with $16 \%$ of the learners from Wozanibone (seven learners in each school). It is interesting to note that all 14 learners in this subgroup mentioned that they would download climate- and environment-related articles and information booklets. They also mentioned their excitement about talking to others (peers and parents) about their passion for the environment and that they enjoyed learning about environmental matters in the class context. They generally also articulated their perceptions of climate change and their role in mitigating its impacts in a fairly positive tone. The respondents used framing such as 'We are empowered', 'We have the technology to solve this problem' 'It is up to our generation', 'We should care'. So, interestingly, these respondents generally had high climate change literacy scores, despite the possibility that they might have read about misconceptions and disagreements in the media.

An assumption underlying the study was that the physio-cultural milieu of learners (as detailed in Table 3) would affect their perceptions of climate change. The conjecture was that, in periurban contexts where class sizes are bigger and resources might be more restricted, with lower levels of access to electronic media, learners would show lower levels of climate change literacy, resulting in ill-informed notions and perceptions of climate change. From the results obtained, however, the performance of the learners in both schools seems to cluster in the 'moderate climate change literacy' segment (with both schools being in the 60\% range). In this subgroup, only a small 
portion of the learners mentioned that they would download or read additional information on the environment or climate change. In addition, they rarely talked to their peers or parents about contemporary societal issues and generally did not enjoy class participation or discussions regarding these matters. The level of 'apathy' and disinterest is quite evident among this grouping of learners. Four of these learners made statements basically engendering fear about climate change. One respondent reflected: 'They don't really seem to know what is going on... . There is so much [disagreement] amongst these scientists... . How must I know what to do, or my role in it? They need to figure things out first'. Another wrote: 'Well we will be dying in any case, right? Either from drought or heat or new diseases!'

Finally, the 'low climate literacy' segment comprised learners who admitted to complete disinterest in the topic. Their perceptions regarding climate change and its impacts signalled a clear message of apathy and disconnect. Responses ranged from 'I really don't care' to 'Who cares'. One respondent wrote: 'I would never waste valuable data on downloading stuff about the environment. I am not crazy.'

\section{Discussion}

The study found that the Grade 11 Geography learners were aware of climate change and had knowledge of it, but misconceptions did occur. More than $60 \%$ of all the respondents (in both schools) had misconceptions about the occurrence of climate change. For example, learners thought that ozone-layer depletion, cigarette smoking and air pollution exacerbated climate change, and that unleaded petrol also contributed to global warming. More than $60 \%$ of the respondents indicated that an increase in temperature would be a consistent phenomenon manifesting itself uniformly over the planet, with all areas of the land surface becoming drier and unsuitable for farming. There were also misconceptions directly linking ozone-layer depletion and climate variability. In the graphic representations, the learners' conflation of greenhouse impacts and climate change impacts was informative, especially when a teacher explained that a sequential approach is used in the curriculum and that the students tend to remember only the graphic representation of the greenhouse gas effect.

The results were actually contrary to what we had expected to find. We had anticipated that the learners from the better-equipped (urban) school, where learners were in smaller classes and had greater access to electronic media, would have higher 'knowledgeability' scores on all aspects. This finding should, of course, be contextualised, as the study is in no way confirmatory of any representative sample. But the learners from the peri-urban school did perform better in answering questions on climate change that required the reproduction of facts taught in the formal curriculum. When it came to the conceptualisation questions, which are also covered in the curriculum but demand a bit more application, the learners in the urban context did in fact outperform their peri-urban counterparts: $83 \%$ of learners in the urban school performed well, while only $50 \%$ of learners in the peri-urban school also did well in these questions. When it came to knowledge of processes, or what could be done about climate change, the peri-urban learners far outperformed the urban learners. A mere $16 \%$ of the urban learners were able to perform well in the section of the questionnaire dealing with solutions to climate change and what they themselves could do. 
Since all the learners were exposed to the same content, one then needs to consider contextual factors such as the teaching methods used by different teachers, or, as in this study, the learners' interactions with peers, parents and electronic media. The findings suggest that greater access to electronic media did not always result in a greater understanding of the solutions to climate change. The urban learners had greater access to media, and were somewhat better than the rural learners at articulating their own solutions to climate change, but still struggled to answer the question (resulting in a $28 \%$ score as against $16 \%$ ). When probed about the reasons for their relatively poor performance, one of the urban learners asked why they had not been allowed to google mitigation strategies.

The content covered in formal schooling is clearly important, but the relatively small group of learners who outperformed everybody else were those who, in addition to the information they received at school, 'constructed' their perception and understanding of climate change through their social interaction with peers, parents and electronic media. The research thus highlights the embedded nature of learners who are also exposed to different arenas of influence such as the media, parents and peers, ultimately helping them to shape their perceptions and understanding of climatic processes and to develop a positive sense of agency to address these.

\section{Conclusion}

In this paper, it has been argued that the nature of the perceptions or understanding of learners regarding climate change fostered in the formal education environment should also be understood in the context of their potential exposure to: (1) alarmist framings about climate change in the media; (2) conceptual disagreements among members in the climate change research community; and (3) the influences of their peers and parents. The study demonstrated that learners in the same education context constructed their learning and perceptions differently. The paper argued that learners' perceptions of climate change also need to be understood as a cumulative outcome of contesting dynamics from these diverging 'arenas of exposure' and, instead of avoiding this, future climate change education planning should make proactive attempts to align and accommodate contending views that might influence the learning process.

\section{Notes on the Contributors}

Mapaleng Silas Lekgeu is currently registered for a masters in Environment and Society in the Department of Geography, Geo-informatics and Meteorology at the University of Pretoria, South Africa. He is also employed as a Geography subject specialist at Umalusi.

Dr Nerhene Davis is a lecturer in the Department of Geography, Geo-informatics and Meteorology at the University of Pretoria, South Africa. She is a social geographer by profession and has interests in rural development, sustainable rural livelihoods and land reform, tenure security, and environmental justice. 


\section{References}

Anyanwu, R., Le Grange, L. \& Beets, P. (2015). Climate change science: The literacy of geography teachers in the Western Cape province, South Africa. South African Journal of Education, 35(3), 1-9.

Bogner, F.X. \& Wiseman, M. (1997). Environmental perception of rural and urban pupils. Journal of Environmental Psychology, 17(2), 111-122.

Boyes, E., Chuchran, D. \& Stanisstreet, M. (1993). How do high school students perceive global climate change; what are its manifestations, what are its origins? What corrective action can be taken? Journal of Science Education and Technology, 2(4), 541-557.

Boyes, E. \& Stanisstreet, M. (2001). Plus ca change, plus c'est la meme chose? School students' ideas about the 'greenhouse effect' a decade on. Canadian Journal of Environmental Education, 6(1), 77-101.

Capstick, S., Whitmarsh, L., Poortinga, W., Pidgeon, N. \& Upham, P. (2015). International trends in public perceptions of climate change over the past quarter century. WIREs Climate Change, 6, 35-61. doi:10.1002/wcc.321.

City of Tshwane. (2014). City of Tshwane: Regional integrated development plan (2014-2015). Retrieved from www.tshwane.gov.za, visited on 25 May 2017.

Daniel, B., Stanisstreet, M. \& Boyes, E. (2004). How can we best reduce global warming? School students' ideas and misconceptions. International Journal of Environmental Studies, 61(2), 211-222.

Hammersley, M. \& Traianou, A. (2012). Ethics and educational research. British Educational Research Association. https://www.bera.ac.uk/researchers-resources/publications/ethicsand-educational-research.

Ho, E. (2009). Children's ideas about climate change. Doctoral thesis, Department of Geography and Collaborative Program in Environmental Studies, University of Toronto.

Kim. (2001). Social Constructivism. In M. Orey (Ed.). Emerging perspectives on learning, teaching and technology. Retrieved from www.http://epltt.coe.uga.edu, visited on 13 June 2017.

Kollmuss, A. \& Agyeman, J. (2002). Mind the gap:Why do people act environmentally and what are the barriers to pro-environmental behaviour? Environmental Education Research, 8(3), 239-260.

Leftridge, A. \& James, R.K. (1980). A study of the perceptions of environmental issues of urban and rural high school students. Journal of Environmental Education, 12(1), 3-7.

Liarakou, G., Athanasiadis, I. \& Gavrilakis, C. (2011). What Greek secondary school students believe about climate change? Internal Journal of Environmental \& Science Education, 6(1), 79-98.

Lotz-Sisitka, H. (2009). Sigtuna think piece 8: Piecing together conceptual framings for climate change education research in Southern African contexts. Southern African Journal of Environmental Education, 26, 81-92.

Lutz, A.R., Simpson-Housley, P. \& De Man, A.F. (1999). Wilderness: Rural and urban attitudes and perceptions. Environment and Behavior, 31(2), 259-266.

Ojala, M. (2015). Climate change scepticism among adolescents. Journal of Youth Studies. http:// dx.doi.org/10.1080/13676261.2015.1020927. 
Palincsar, A.S. (1998). Social constructivist perspectives on teaching and learning. Educational studies. Annual Review of Psychology, 49, 345-375.

Palinkas, L.A., Horwitz, S.M., Green, C.A., Wisdom, J.P., Duan, N. \& Hoagwood, K. (2013). Purposeful sampling for qualitative data collection and analysis in mixed method implementation research. Administration and Policy in Mental Health, 42(5), 533-544.

Pruneau, D., Gravel, H., Bourque, W. \& Langis, J. (2003). Experimentation with a socioconstructivist process for climate change. Environmental Education Research, 9(4), 429-446.

Pruneau, D., Khattabi, A. \& Demers, M. (2008). Educating and communicating about climate change - challenges and possibilities. Project ACCMA.

Shahadu, H. (2012). Youth understanding of climate: Towards a theory of social adaptation to climate change in Africa. Masters dissertation, Department of Media and Communications, London School of Economics and Political Science.

Shenton. (2004). Strategies for ensuring trustworthiness in qualitative research projects. Education for Information, 22, 63-75.

Shepardson, D.P., Niyogi, D., Choi, S. \& Charusombat, U. (2009). Student conception about global warming and climate change. National Science Foundation, Purdue University.

South Africa (Government of the Republic of South Africa). (2011). The National Development Plan (NDP). Pretoria.

South Africa (Government of the Republic of South Africa). (2012). Curriculum and Assessment Policy Statement (CAPS). Pretoria.

Statistics South Africa (2003). Census 2001: Investigation into appropriate definitions of urban and rural areas for South Africa. Discussion document. Pretoria: Statistics South Africa.

Stewart, C.T. Jr (1958). The urban-rural dichotomy: Concepts and uses. The American Journal of Sociology, 64(2), 152-158.

Swim, J., Clayton, S., Doherty, T., Gifford, R., Howard, G., Reser, J., ... Weber, E. (2009). Psychology and global climate change: Addressing a multifaceted phenomenon and set of challenges. http://www.apa.org/science/about/publications/climate-change-booklet.pdf, visited 13 August 2012.

Vujovic, J. (2013). FET geography teachers' knowledge and perceptions of climate change and an evaluation of the textbooks used for climate change education. Unpublished masters dissertation, University of the Witwatersrand.

Whitmarsh, L. (2011). Scepticism and uncertainty about climate change: Dimensions, determinants and change over time. Global Environmental Change, 21, 690-700.

Wibeck, V. (2014). Enhancing learning, communication and public engagement about climate change: Some lessons from recent literature. Environmental Education Research, 20(3), 387-411. 